\title{
METHOD OF MEASURING STRAINS BETWEEN GLAZES AND CERAMIC BODIES
}

\author{
By H. G. Schurecht and G. R. Pole ${ }^{1}$
}

\section{ABSTRACT}

A new test was developed for comparing the strains existing between different glazes or other ceramic finishes and the bodies to which they are applied. By its use these strains may be so adjusted that the finishes will be in sufficient compression to prevent crazing from subsequent expansion of the body without causing initial shivering. The new test is particularly valuable because the measurements are made on combinations of glaze and body prepared and treated almost exactly like those intended for regular use and beeause of the simplicity and cheapness of the apparatus required. A modification of the test provides a comparison of the moisture expansions of different bodies.

\section{CONTENTS}

I. 'Introduction

II. Experimental methods. 98

III. Results of tests on newly fired ware 100

IV. The ring test as a means of measuring moisture expansions of ceramic bodies.

V. Summary and conclusions. 104

\section{INTRODUCTION}

In selecting glazes or other finishes for ceramic bodies it is essential to know to what extent the finish may be in compression or in tension without causing delayed crazing ${ }^{2}$ or shivering. If a glaze is in strong: compression on newly fired bodies it is not likely to be thrown into tension from the subsequent expansion of the body. It is therefore less apt to develop delayed crazing than a glaze in tension or only under slight compression. If a ceramic finish is under excessive compression it may shiver.

The purpose of this work was to develop a simple, cheap, and rapid means for measuring the strains existing between glazes and the bodies to which they are applied. This test will also be of assistance in developing new glazes and bodies on which the glaze should be in adequate compression to prevent crazing, but still should not be in sufficient compression to cause shivering.

1 Research associates of the National Terra Cotta Society at the National Bureau of Standards.

2 Method of Testing Crazing of Glazes Caused by Increases in Size of Ceramic Bodies, J. Am. Ceram. Soc., 11, pp. 271-272; 1928. 


\section{EXPERIMENTAL METHODS}

The specimens used for these tests are 2-inch diameter hollow cylindrical rings with the glaze or other ceramic finish to be tested applied to the outside only. (See fig. 1.) Care must be taken not to glaze the inside surface or edges, otherwise an error would be introduced.

After firing, two grooves or holes are cut in one edge of the ring approximately one-fourth inch apart and large enough to hold glass capillary tubes one-eighth inch long and one thirty-second inch in diameter. These thin capillary tubes are prepared by heating thicker tubes and drawing them down to a thread to make the
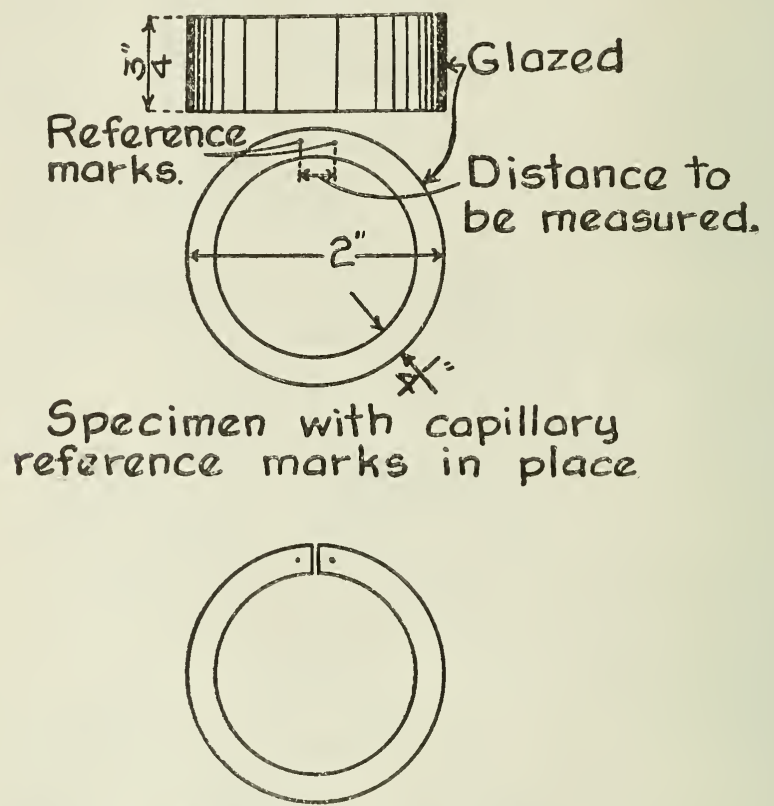

\section{Specimen cut open between} the reference marks.

FIGURE 1.-Sketch of ring specimen

capillary holes small, and thus provide sharp reference marks when observed under the microscope. They are cemented in the holes or grooves with a litharge glycerin mixture or other suitable adhesive. The distance between the two reference marks is then measured as accurately as possible with a micrometer microscope similar to that shown in Figure $2 .^{3}$

The rings are then cut open between the reference marks with a diamond saw or a narrow crystalon grinding wheel. By remeasuring these distances after cutting, the expansions or contractions of the rings may be observed. The expansions or contractions of rings with $n$ glaze are also determined, and these are subtracted from the

${ }^{3}$ In making these measurements it is important to keep the reference marks as nearly parallel to the horizontal cross hair or direction of measurement as possible. 
measurements obtained on the corresponding glazed rings to obtain the true expansions or contractions caused by partially releasing the strains between the glaze and body.

If the glazes are in tension the ring will expand when cut open, but if in compression it will contract. Hence, the expansion or contraction of the rings may be used as approximate measurements of whether the glazes are in tension or compression.

In the work reported in this paper the expansion or contraction of the rings was determined as described above by one measurement without attempting to determine the actual stresses in the glazes.

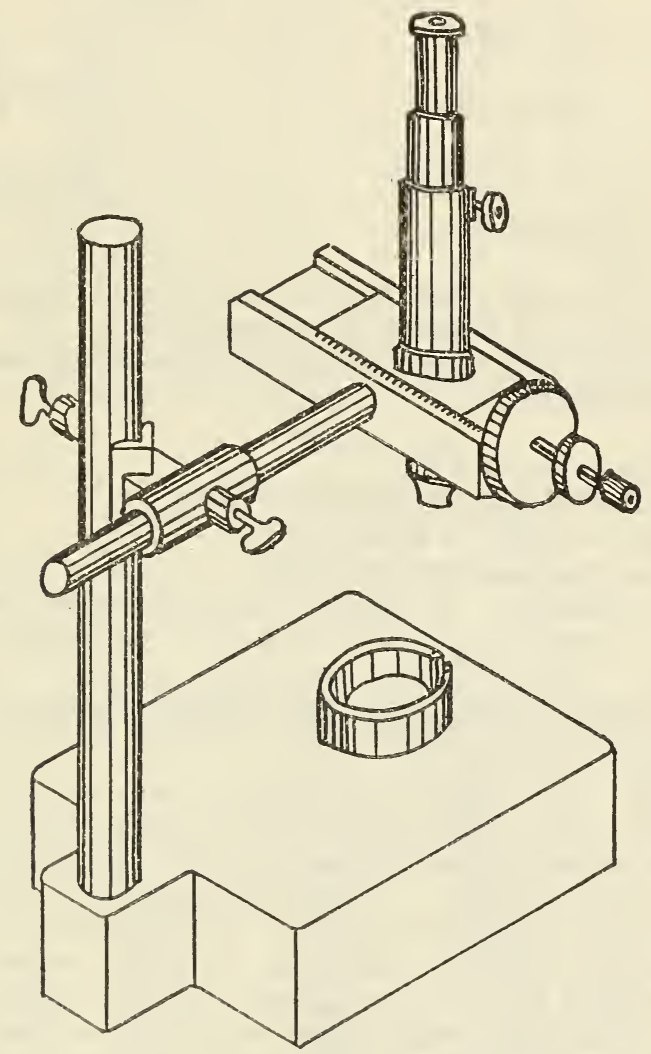

FigURe 2.-A pparatus used to measure the expansion or contraction of rings

To determine the actual stresses in the glazes would be too involved for plant control and most laboratory work, in which cases it is merely desired to know if the glaze is in tension or compression and approximately how much.

The maximum stresses which have been released in the body and glaze by cutting the rings open may be also determined with Merriman's ${ }^{4}$ curved beam formula.

In Figure 3, $a b$ represents the change in length of the inside, while $A B$ represents the change in length of the outside of the curved beam 
due to cutting the ring open. These changes in length may be measured directly between short distances on the outside and inside of

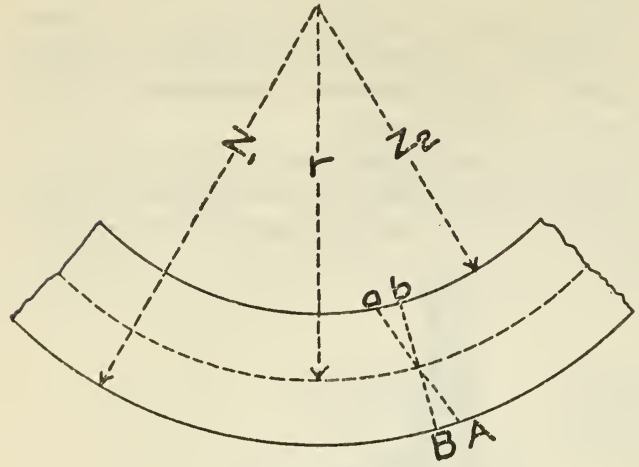

FIgURE 3 the rings by means of the micrometer microscope. From these data the angle between $A a$ and $B b$ may be calculated. The curved beam formulas for calculating the maximum fiber stresses in this case are as follows:

$$
\begin{aligned}
& S_{1}=E_{1} \frac{d \theta}{\theta} \frac{z_{1}-r}{z_{1}} \\
& S_{2}=E_{2} \frac{d \theta}{\theta} \frac{z_{2}-r}{z_{2}}
\end{aligned}
$$

$S_{1}=$ maximum fiber unit stress which was released on glaze by cutting open the ring, in pounds per square inch.

$S_{2}=$ maximum fiber unit stress which was released on body, in pounds per square inch.

$\theta=360^{\circ}$.

$d \theta=$ angle between $A a$ and $B b$.

$z_{1}=$ outside radius of ring, in inches.

$z_{2}=$ inside radius of ring, in inches.

$r=$ radius of neutral surface, in inches.

$E_{1}=$ modulus of elasticity of glazes, in pounds per square inch.

$E_{2}=$ modulus of elasticity of body, in pounds per square inch.

\section{RESULTS OF TESTS ON NEWLY FIRED WARE}

To determine how much a slip finish may be in tension before it crazes and also how much it may be in compression before it shivers, 24 bodies were prepared with coefficients of thermal expansion varying from $5 \times 10^{-6}$ to $13.2 \times 10^{-6}$. These coefficients were calculated from interferometer measurements between $20^{\circ}$ and $600^{\circ} \mathrm{C}$. made on the separate burned clays from which the 24 bodies were compounded. These were molded into ring specimens and the same vitreous slip finish applied to all, after which they were fired to cone 6 .

The average results of strain tests made on five duplicate rings are given in Table 1 and plotted in Figure 4. It is apparent that a slip tinish may be in compression sufficient to cause a contraction of the ring of $0.0308 \mathrm{~cm}$ in circumference without shivering. The values obtained where the slip had crazed are too low, since some of the strain between body and slip has been relieved through crazing of the slip. By examining results which show the slip to be in tension but still sound, it is apparent that the slip may cause the rings to expand $0.0071 \mathrm{~cm}$ in circumference without crazing. If, however, the expansion is higher, it may develop crazing. It is apparent that this slip can be under considerable compression before it shivers, but crazing may occur when under a comparatively small tension. 


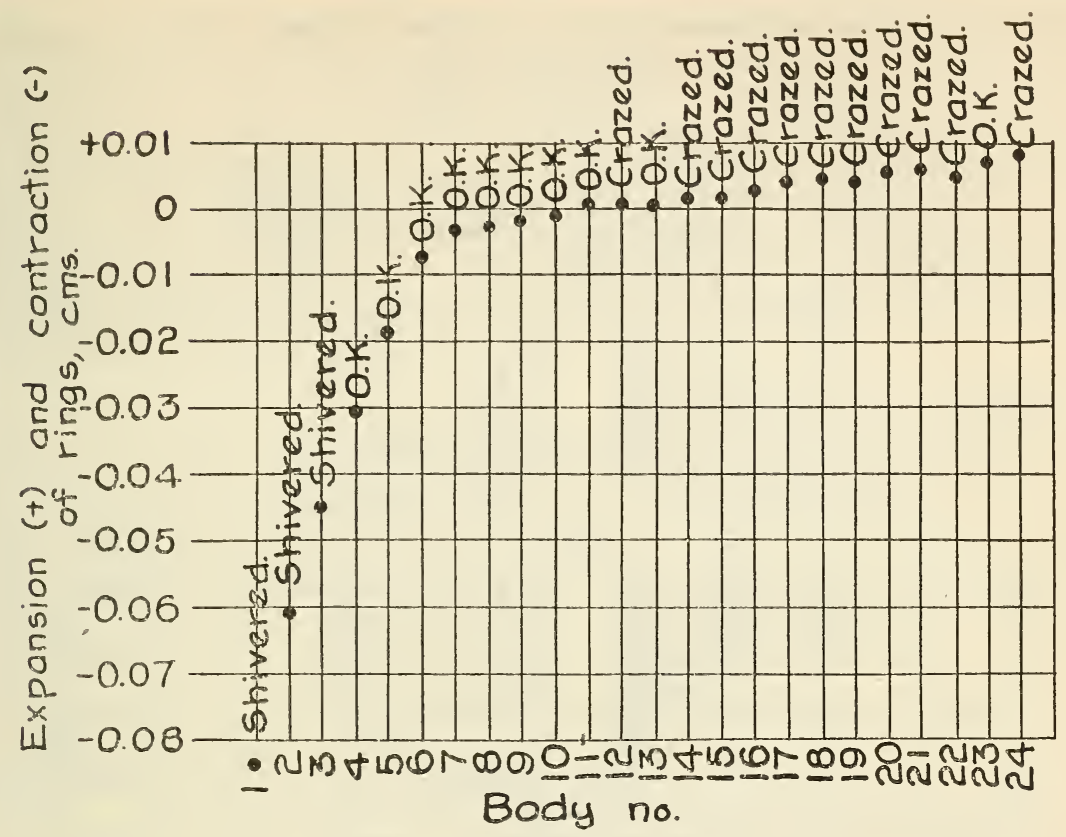

FIGURE 4.-Relation between expansions and contractions of rings and the tendency of glazes to craze or shiver

TABLE 1.-The relation between ring tests and the tendency of a slip finish to craze or shiver

\begin{tabular}{|c|c|c|c|c|}
\hline $\begin{array}{l}\text { Special } \\
\text { bodies }\end{array}$ & $\begin{array}{c}\text { Expansions (+) } \\
\text { or contractions } \\
(-) \text { of rings } \\
\text { with no glaze } \\
A\end{array}$ & $\begin{array}{c}\text { Expansions (+) } \\
\text { or contractions } \\
(-) \text { of glazed } \\
\text { rings after cut- } \\
\text { ting } \\
B\end{array}$ & $\begin{array}{l}\text { Expansions (+) } \\
\text { or contractions } \\
(-) \text { of glazed } \\
\text { rings due to } \\
\text { strains between } \\
\text { glaze and body } \\
(B-A)\end{array}$ & $\begin{array}{l}\text { Condition of } \\
\text { glaze when } \\
\text { removed } \\
\text { from kiln }\end{array}$ \\
\hline $\begin{array}{l}1 \\
2 \\
3 \\
5 \\
5\end{array}$ & $\begin{array}{c}c m \\
+0.0004 \\
-.0026 \\
+.0008 \\
-.0003 \\
-.0009\end{array}$ & $\begin{array}{c}c m \\
-0.0844 \\
-.0631 \\
-.0446 \\
-.0311 \\
-.0197\end{array}$ & $\begin{array}{c}c m \\
-0.0848 \\
-.0605 \\
-.0454 \\
-.0308 \\
-.0188\end{array}$ & $\begin{array}{c}\text { Shivered. } \\
\text { Do. } \\
\text { Do. } \\
\text { O. K. } \\
\text { O. K. }\end{array}$ \\
\hline $\begin{array}{l}6 \\
7 \\
7 \\
8 \\
9 \\
10 \\
-\ldots . . .\end{array}$ & $\begin{array}{l}-.0021 \\
+.0006 \\
+.0012 \\
+.0001 \\
+.0015\end{array}$ & $\begin{array}{l}-.0097 \\
-.0029 \\
-.0009 \\
-.0016 \\
+.0006\end{array}$ & $\begin{array}{l}-.0076 \\
-.0035 \\
-.0021 \\
-.0015 \\
-.0009\end{array}$ & $\begin{array}{l}\text { O. K. } \\
\text { O. K. } \\
\text { O. } \frac{\mathrm{K}}{\mathrm{K}} \\
\text { O. } \\
\text { O. } \mathrm{K} .\end{array}$ \\
\hline $\begin{array}{l}11 \ldots \ldots \\
12 \ldots \ldots \\
13 \ldots \ldots \\
14 \ldots \ldots \\
15 \ldots . . .\end{array}$ & $\begin{array}{l}+.0013 \\
+.0007 \\
+.0009 \\
+.0004 \\
+.0006\end{array}$ & $\begin{array}{l}+.0004 \\
+.0009 \\
+.0010 \\
+.0018 \\
+.0020\end{array}$ & $\begin{array}{l}+.0009 \\
1+.0002+ \\
+.0001 \\
+.0014+ \\
+.0014+\end{array}$ & $\begin{array}{l}\text { O. K. } \\
\text { Crazed. } \\
\text { O. K. } \\
\text { Crazed. } \\
\text { Do. }\end{array}$ \\
\hline $\begin{array}{l}16 \ldots \\
17 \\
18 \ldots \ldots \\
19 \\
20 \ldots \ldots\end{array}$ & $\begin{array}{l}+.0009 \\
-.0002 \\
-.0006 \\
+.0006 \\
-.0006\end{array}$ & $\begin{array}{l}+.0031 \\
+.0034 \\
+.0037 \\
+.0039 \\
+.0049\end{array}$ & $\begin{array}{l}+.0022+ \\
+.0036+ \\
+.0043+ \\
+.0033+ \\
+.0055+\end{array}$ & $\begin{array}{l}\text { Do. } \\
\text { Do. } \\
\text { Do. } \\
\text { Do. } \\
\text { Do. }\end{array}$ \\
\hline $\begin{array}{l}21 \\
22 \\
23 \\
24\end{array}$ & $\begin{array}{l}+.0004 \\
+.0009 \\
+.0015 \\
+.0015\end{array}$ & $\begin{array}{l}+.0056 \\
+.0057 \\
+.0086 \\
+.0096\end{array}$ & $\begin{array}{l}+.0060+ \\
+.0048+ \\
+.0071 \\
+.0081\end{array}$ & $\begin{array}{l}\text { Do. } \\
\text { Do. } \\
\text { O. K. } \\
\text { Crazed. }\end{array}$ \\
\hline
\end{tabular}

1 The expansions of rings which were crazed when removed from the kiln are marked plus, since some of the strain between the body and slip has been relieved by crazing of the slip. 
TABLE 2.-The relation between ring tests and the tendency of different ceramic finishes to craze

BRIGHT GLAZES

\begin{tabular}{|c|c|c|c|}
\hline & $\begin{array}{l}\text { Expansions }(+) \\
\text { or contractions } \\
(-) \text { of glazed } \\
\text { rings due to } \\
\text { strains between } \\
\text { glaze and body }\end{array}$ & $\begin{array}{l}\text { Condition of } \\
\text { glaze when } \\
\text { removed from } \\
\text { kiln }\end{array}$ & $\begin{array}{l}\text { Condition of } \\
\text { glaze after } \\
\text { treatment with } \\
\text { steam at } 150 \\
\text { lbs./in. } 2 \\
\text { for } 1 \text { hour }\end{array}$ \\
\hline $\begin{array}{l}1 \\
2 \\
3 \\
5 \\
6\end{array}$ & $\begin{array}{c}c m \\
-0.0063 \\
-.0033 \\
.0018+ \\
.0080+ \\
.0012+ \\
.0130+\end{array}$ & 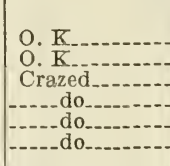 & $\begin{array}{l}\text { O. K. } \\
\text { O. }\end{array}$ \\
\hline \multicolumn{4}{|c|}{ MAT GLAZES } \\
\hline $\begin{array}{l}1-\cdots \\
2-\cdots \\
3-\cdots \\
4-\cdots \\
5 \\
6-\cdots \\
7-\cdots\end{array}$ & $\begin{array}{l}-0.0140 \\
-.0106 \\
=.0103 \\
=.0043 \\
-.0005 \\
.0030+ \\
.0033+\end{array}$ & $\begin{array}{l}\text { O. K } \\
\text { O. } \mathrm{K} \\
\text { O. } \mathrm{K} \\
\text { O. } \mathrm{K} \\
\text { O. } \mathrm{K} \\
\text { Crazed } \\
\end{array}$ & $\begin{array}{l}\text { O. K. } \\
\text { O. K. } \\
\text { O. K. } \\
\text { O. K. } \\
\text { Crazed. }\end{array}$ \\
\hline \multicolumn{4}{|c|}{ SLIP FINISHES } \\
\hline $\begin{array}{l}1 \\
1 \\
2 \\
3 \\
4 \\
5\end{array}$ & $\begin{array}{c}-0.0066 \\
.0020+ \\
.0040+ \\
.0063+ \\
.0090+\end{array}$ & $\begin{array}{l}\text { O. K } \\
\text { Crazed } \\
-d d_{-} \\
\\
\end{array}$ & O. K. \\
\hline
\end{tabular}

The results of similar tests with different glazes and slip finishes are given in Table 2. It is evident from these that glazes or slips in strong compression on newly fired bodies do not craze even when treated with steam at $150 \mathrm{lbs} . / \mathrm{in} .^{2}$ for one hour. However, all glazes which were in tension when removed from the kiln were crazed. It seems, therefore, that the use of glazes which are under strong compression on newly fired ware would tend to obviate delayed crazing due to moisture.

These tests confirm previous work done on glazes by the autoclave ${ }^{5}$ and interferometer methods. ${ }^{6}$

In general, the mat glazes were found to be in greater compression than the other ceramic finishes tested, although some mat glazes were not as good in this respect as certain bright glazes. This apparently shows that the mat glazes tested have a lower thermal expansion than the other glazes.

\section{THE RING TEST AS A MEANS OF MEASURING MOISTURE EXPANSIONS OF CERAMIC BODIES}

Since certain ceramic bodies expand when treated with water while the glaze remains relatively constant in size, it is obvious that open glazed rings may be used to obtain an approximate measure-

\footnotetext{
8 II. G. Schurecht, Methods of Testing Crazing of Clnzes Caused by Increase in Size of Ceramic Bodies, J. $\Delta \mathrm{m}$. Ceram. soc., 11, No. $6 ; 1928$.

o George Merritt, Application of the Interferometer to Measurements of the Thermal Dilatation of Ceramic Materials, B. S. Sci. Paper No. 485; 1921.
} 
ment of the moisture expansions of ceramic bodies. Rings and bars of the same body were prepared for the purpose of comparing the expansions obtained in the two tests when the specimens were subjected to the same treatments. They were completely immersed in water for seven days, after which the distances between the reference marks were measured while wet and also after drying at $110^{\circ} \mathrm{C}$. for 12 hours. These distances were also measured subsequent to subjecting them to steam at a pressure of $150 \mathrm{lbs} . / \mathrm{in} .{ }^{2}$ for one hour. By this means the same ring can be used as a measure of the strain and also as an approximation of the moisture expansion.

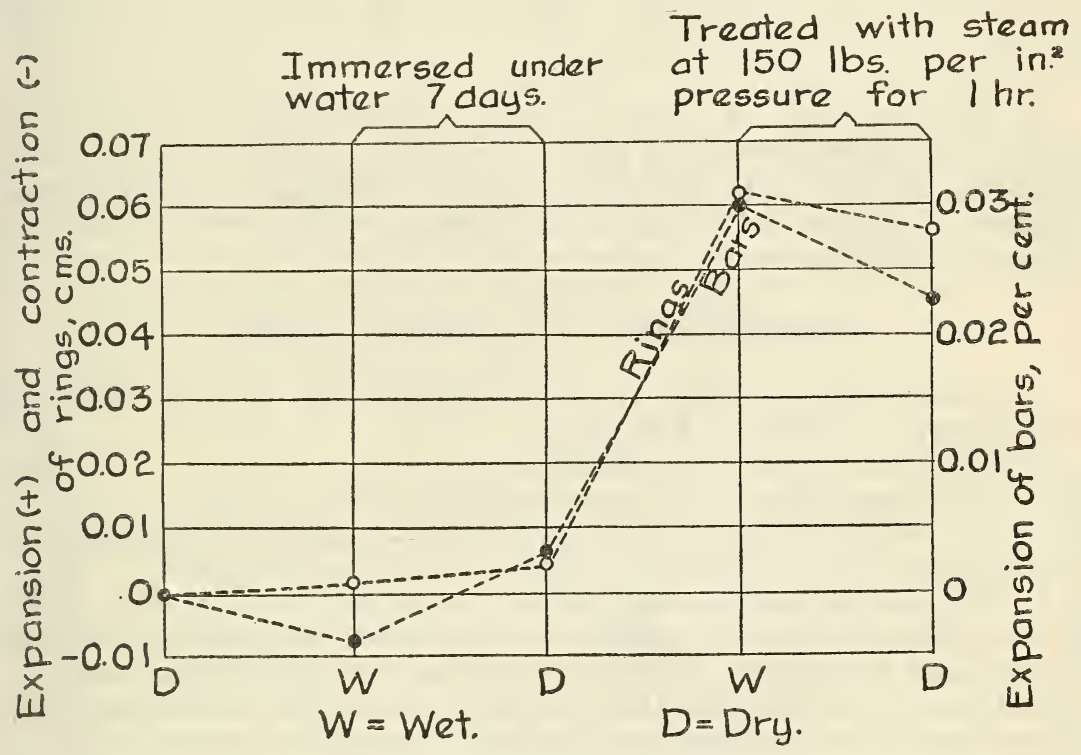

Figure 5.-A comparison of the moisture expansions of a ceramic body and the expansion of rings

The results obtained with glazed rings, cut open between the reference marks, and bars made of the same body have been plotted in Figure 5. It is evident that the expansions of the rings are approximately proportional to those of the bars.

Similar data for a number of other bodies are given in Table 3. From these data it is again evident that the expansions of the rings, in general, increase as the expansions of the bars increase. Although the ring moisture expansion test is not as accurate as the bar moisture expansion test, it can be conducted in less time and with inexpensive equipment. 
TABLE 3.-Expansions of rings and bars caused by autoclave treatment

\begin{tabular}{|c|c|c|}
\hline & $\begin{array}{c}\text { Treated in an autoclave at } \\
\text { a steam pressure of 150 } \\
\text { lbs./in. } .^{2} \text { for } 1 \text { hour }\end{array}$ \\
\cline { 1 - 2 } & $\begin{array}{c}\text { Expansion } \\
\text { of rings }\end{array}$ & $\begin{array}{c}\text { Expansion } \\
\text { of bars }\end{array}$ \\
\hline & $c m$ & Per cent \\
1 & 0.0043 \\
2 & .0064 & .039 \\
45 & .0111 & .057 \\
\hline 5 & .0089 & .042 \\
\hline
\end{tabular}

As an illustration of further possible applications of ring tests in ceramics it might be stated that it has been planned to use modifications of this test in future work to compare the resistance of ceramic finishes to strain and to determine the annealing temperatures of glazes and other ceramic finishes.

\section{SUMMARY AND CONCLUSIONS}

1. A test was developed for measuring strains between glazes or other ceramic finishes and bodies.

2. Glazes can be under considerable compression without shivering, but they craze when under comparatively small tension.

3. The simplicity and ease of making the ring test on ceramic finishes admirably suit it as a means of plant control work.

4. With the aid of the ring test it is possible to fit glazes to bodies so that they will be in sufficient compression to prevent moisture crazing and still not be in compression enough to cause shivering.

5. It was demonstrated that the ring test may be used to compare approximately the moisture expansions of ceramic bodies.

6. In general, it was found that mat glazes, owing to their lower thermal expansions, are in stronger compression on ceramic bodies than bright glazes and hence are more resistant to crazing.

Washington, October 16, 1929. 